Sudrajat, Nugraheni C.P; Yunike, S.; \& Dwi S., A.

\title{
PRIBUMISASI ILMU-ILMU SOSIAL DAN PEMBARUAN PEMBELAJARAN IPS TERPADU DI SEKOLAH
}

Oleh:

Sudrajat, Nugraheni C.P; Yunike, S.; \& Dwi S., A.

Program Pascsarjana

Universitas Negeri Yogyakarta

Email: sudrajat@uny.ac.id

\begin{abstract}
Abstrak
Ilmu sosial di negara berkembang (salah satunya Indonesia) masih menggunakan paradigma ilmu sosial di Barat (Eropa) sehingga dalam beberapa kasus menjadi tidak relevan ketika digunakan untuk memecahkan masalah sosial. Penelitian menggunakan metode kajian pustaka yaitu sebuah pencarian kebenaran secara otoritatif melalui pendapat dan kajian ahli yang dituliskan dalam buku dan referensi. Hasil kajian menemukan bahwa perkembangan ilmu sosial di Indonesia memang tidak dapat dilepaskan dari dunia Barat. Pribumisasi merupakan wacana untuk menumbuhkan pemikiran baru dalam ilmu-ilmu sosial di Indonesia agar lebih kontekstual. Beberapa tokoh menawarkan teori sosial alternatif yang mengkedepankan pribumisasi ilmu sosial yaitu: Kuntowoyo, Sartono Kartodirjo, Mubyarto, Purwa Santoso, dan Zamroni. Upaya pribumisasi harus ditindaklanjuti dengan mengajarkan ilmu sosial alternatif dalam berbagai jenjang pendidikan. Pembaruan IPS Terpadu dengan pembelajaran alternatif menjadi upaya yang efektif untuk membumikan ilmu sosial yang khas Indonesia.

Kata Kunci : Ilmu Sosial, Pribumisasi, Pembelajaran IPS Terpadu
\end{abstract}

\begin{abstract}
Social science in developing countries (one of which is Indonesia) still uses the social science European paradigm. So that in some cases becomes irrelevant to solve social problems in Indonesia. The research uses literature study method, which is an authoritative truth search through opinions of expert in written expression in books, journals, and references. The study found that the development of social science in Indonesia cannot be separated from the Western world. Indigeous is a discourse to foster new thinking in the social sciences in Indonesia to be more contextual. Some figures offer alternative social theories that prioritize the indigenization of social science, namely: Kuntowijoyo, Sartono Kartodirjo, Mubyarto, Purwa Santoso, and Zamroni. Indigenous efforts must be followed up by teaching alternative social sciences at various levels of education. The renewal of integrated social studies with alternative learning has become an effective effort to ground Indonesian social sciences.

Keyword: Social sciences, indigenous, Integrated Social Science learning.
\end{abstract}




\section{Pendahuluan}

Manusia sebagai makhluk sosial, selalu dihadapkan pada berbagai masalah sosial, yang hakikatnya merupakan bagian yang tidak dipisahkan dari kehidupan manusia itu sendiri. Masalah sosial telah terwujud sebagai hasil kebudayaan manusia itu sendiri, sebagai akibat dari hubungannya dengan manusia lainnya. Masalah sosial pada setiap masyarakat berbeda dari masyarakat satu sama lain karena adanya tingkat perkembangan kebudayaan dan masyarakatnya yang berbeda. Masalah-masalah tersebut terwujud sebagai masalah sosial, masalah moral, masalah politik, masalah agama dan masalah lainnya. Yang membedakan masalah sosial dari masalah lainnya adalah masalah sosial selalu berkaitan dengan nilainilai moral dan pranata sosial serta selalu berkaitan dengan hubungan manusia dan dengan konteks-konteks normatif tempat hubungan manusia terwujud. Rasa permusuhan timbul antar negara, pertentangan antara kaum borjuis dan kaum buruh, kemiskinan, kebodohan, ketimpangan, dan lain-lain.

Masalah kaum buruh yang lebih menginginkan keuntungan ekonomis jangka pendek merupakan masalah juga. Kemenangan jangka panjang yang membawa kebahagiaan mereka, dilupakan dan lebih memilih menerima upah harian yang adil dibanding memperjuangkan penghapusan buruh upah. Selanjutnya di tahun 1960-an muncul kaum perempuan aktif dalam melawan penindasan seksual. Gerakan mahasiswa muncul sebagai aksi kritis terhadap penindasan dan ketidakadilan yang ada. Minoritas etnis melancarkan protes melawan diskriminasi resmi dan tidak resmi yang terus berkelanjutan. Kehidupan lebih demokratis dengan adanya kebebasan tiap individu dalam kancah politik maupun pemerintah (Nasiwan, 2014: 107).

Permasalahan yang muncul di masyarakat, memunculkan ilmu sosial untuk dapat memberikan alternatif dalam memecahkan 
masalah-masalah tersebut. Ilmu-ilmu sosial tumbuh dari filsafat moral, sebagaimana ilmu-ilmu alam tumbuh dari filsafat alam. Perkembangan ilmu-ilmu sosial di Indonesia tidak lepas dari pengaruh perkembangan ilmu sosial yang ada di Barat. Perkembangan ilmu sosial di Indonesia lebih didominasi oleh pemikiran barat. Teori sosial barat banyak mempengaruhi pada keilmuan sosial di Indonesia. Fakta bahwa sebagian besar ilmu sosial dan humaniora di masyarakat (negara) berkembang datang dari barat.

Kuatnya pengaruh ilmu sosial barat, lebih disebabkan masalah internal intelektual-akademisi Indonesia sendiri, dimana mereka telah terpuaskan dengan meniru apa yang berkembang di Barat. Padahal ilmu sosial dari barat belum tentu sesuai jika diterapkan pada permasalahan sosial yang di Indonsia. Maka dari itu diperlukan pribumisasi ilmu sosial di Indonesia dengan menggunakan sejarah atau kultur yang sesuai atau dimiliki Indonesia. Karena sejarah merupakan penghubung masa kini dan masa lalu yang bisa memberi gambaran dan pelajaran di masa depan. Pada perkembangan selanjutnya, segala bentuk aktivitas sosial yang ada harus melihat akar historisnya. Masalah-masalah ilmu sosial yang ada dapat dipecahkan secara mendalam dengan mengacu pada perkembangan zaman yang terjadi.

Dahrendorf (Dadang, 2011: 30) merupakan konsep perhatian pada aspek-aspek kemasyarakatan manusia. Ilmu-ilmu sosial tumbuh dari filsafat moral, sebagaiman ilmu-ilmu alam tumbuh dari filsafat alam. Di kalangan filsuf moral Skotlandia, kajian ekonomi politik selalu diikuti oleh kajian isu-isu sosial yang lebih luas, meski tidak disebut sebagai ilmu sosial. Unggulnya postivisme pada awal abad ke-19, terutama di Prancis, mengambil alih filsafat moral. Ilmu sosial pada dasarnya merupakan ilmu yang mempelajari perilaku dan aktivitas manusia dalam kehidupan bersama, bagaimana hubungan manusia dengan manusia dan hubungan manusia dengan 
lingkungannya. Perbedaan utama antara ilmu sosial dengan ilmu alam adalah objeknya. Objek ilmu alam adalah fisik, sedangkan objek ilmu sosial adalah manusia dan hubungannya dengan lingkungannya. Selain mengkaji peirilaku dan aktivitas manusia, ilmu sosial memandang situasi peristiwa umat manusia dari perspektif yang agak berbeda dan unik (Ijtimaiyah, 2018: 7).

Hatta (Nasiwan, 2013) menyampaikan bahwa ilmu sosial sebagaimana ilmu pengetahuan yang lain adalah satu ragam dimana memiliki peran tiga wajah ilmu sosial, pertama: critical discourse (wacana kritis) yaitu membahas apa adanya yang keabsahannya tergantung pada kesetiaan pada prasyarat sistem rasionalitas yang kritis dan pada konvensi akademis yang berlaku. Keabsahan penelitian ditentukan oleh keterikatan pada semua keharusan akademis. Kedua, academic enterprise bahwa ilmu sosial juga harus memikirkan bagaiman mestinya yang memposisikan bahwa ilmu sosial tidak bebas nilai. Ilmu sosial yang ada memiliki nilai-nilai yang terkandung di dalamnya. Ilmu sosial tidak terlepas dari nilai yang melekat padanya. Ilmu sosial sebagai tetangga dekat ideologi, sebagai sistematisasi strategis dari nilai dan filsafat sebagai pandangan hidup. Ketiga applied science yaitu bahwa dalam ilmu sosial itu diperlukan untuk mendapatkan atau mencapai hal-hal yang praktis dan berguna.

Ilmu sosial dibutuhkan untuk memecahkan masalah yang ada di masyarakat, guna mendeskripsikan, memprediksi dan menjawab isuisu sosial. Ilmu sosial mampu menggambarkan fenomena yang terjadi, sehingga dapat dijadikan acuan dalam mengkaji, menganalisis, dan mencari alternatif. Ilmu sosial bukanlah ilmu pengetahuan yang tunggal, bila kita mengajukan pertanyaan dasar ilmu untuk apa, dan ilmu untuk siapa, maka muncul empat tipe sosial yaitu ilmu sosial profesional, ilmu sosial publik, ilmu sosial kebijakan dan ilmu sosial kritis. Perkembangan ilmu sosial yang sehat disuatu negara 
ditandai oleh keseimbangan yang saling melengkapi antar keempat tipe ilmu sosial tersebut (Achwan, 2010: 190). Dalam konteks sejarah ilmu sosial di Indonesia yang dapat dilihat dalam tiga fase perkembangan yang berbeda, yaitu ilmu sosial kolonial (indologi); ilmu sosial develomentalis; dan ilmu sosial kontemporer. Masingmasing fase memiliki karakteristik yang berbeda-beda, bukan saja karena latar belakang zaman yang berbeda, melainkan juga karakteristik isi dan orientasi keilmuannya (Nasiwan \& Wahyuni, 2016: 19).

Pada fase awal, indologie atau ilmu sosial kolonial merupakan corpus pengetahuan yang terlembaga pada mulanya berasal dari kajian indologie, yakni suatu lembaga yang dibentuk oleh pemerintah kolonial di Leiden pada tahun 1848 untuk meyiapkan bekal pengetahuan tentang masyarakat tentang masyarakat negeri jajahan bagi calon administrator yang akan dikirim ke Hindia-Belanda. Zeigest (Iklim intelektual) yang melatarbelakangi gagasan tersebut ialah proses pasifikasi daerah jajahan di Hindi-Belanda. Artinya, setelah peperangan dan menaklukan sebagian besar wilayah Indonesia, pemerintah kolonial memerlukan pengetahuan yang mendalam untuk memahami dan menguasai negeri jajahan. Pada awal mula terpisah dari universitas, tetapi sejak tahun 1891 berkembang menjadi salah satu jurusan di Universitas Leiden dan masuk ke Indonesia dengan orientalisme lewat lembaga-lembaga kolonial di luar institusi akademik. Pada tahun 1920-an didirikanlah beberapa dua perguruan tinggi yang terkait langsung dengan ilmu sosial yaitu Sekolah Tinggi Hukum (Rechtshogeschool, RHS) didirikan 1924 dan fakultas sastra dan filsafat (Fakulteit der Letteren en Wijsbegeerte, FLW) tahun 1940. Ilmuwan sosial pada masa tersebut terutama ilmuwan Belanda yang mempelajari Indonesia seperti: Snouck Hourgronye, BJO Schrieke, Wertheim, van Vollenhoven, Furnivall, Berg, FDK Bosch, de Graff, dan lain-lain. 
Fase kedua yaitu ilmu sosial developmentalis, dimulai sejak berakhirnya Perang Dunia II khususnya sejak tahun 1950-1960-an dimana terjadi pergeseran penting dalam perkembangan ilmu sosial Indonesia dari mainstream sebelumnya (indologie) yang lebih berorientasi Eurosentrisme kepada ilmu sosial baru yang merujuk ke Amerika Serikat (AS). Pergeseran ini terkait dengan zeitgeist dimana terjadi perubahan drastis kondisi politik di Indonesia di satu pihak, dan konstelasi politik dunia. Pertama, untuk ini berhubungan dengan proses dekolonisasi, lewat perang kemerdekaan paska 1945 dan sentimen anti-Belanda yang berujung pada pengusiran semua guru besar Belanda yang mengajar di perguruan tinggi di Indonesia sejak awal 1950-an. Putusnya hubungan antara Belanda dan Indonesia sejak tahun 1950 ternyata berdampak besar terhadap perkembangan ilmu sosial di Indonesia. Ilmuwan sosial pada masa tersebut sebagian mengenyam pendidikan lewat guru-guru Belanda, untuk tidak mengatakan terdidik secara secara indologies, seperti: Soepomo (hukum), T.G.S. Moelia (Sosiologi), Koentjoroningrat (antropologi) Soekmono (Arkeologi), Sartono Kartodirjo (sejarah), Slamet Imam Santoso (psikologi), Wijoyo Nitisastro (ekonomi), dan lain-lain.

Fase ketiga yaitu ilmu sosial Indonesia kontemporer sebagai kelanjutan dari perkembangan sebelumnya, tetapi pada saat yang sama beberapa ciri pokoknya sebagaimana masih tetap ada dan bertahan bertahan sampai sekarang. Pertengahan tahun 1960-an perkembangan ilmu sosial di Indonesia belum bisa berkembang, baik profesi dan/atau komunitas ilmuan sosialnya, maupun lembaga penelitian dan pendidikan ilmu-ilmu sosial yang lebih professional. Namun sejak tahun 1970-an, sejalan dengan kembalinya para sarjana ilmu sosial yang belajar di luar negeri tampaknya terdapat perkembangan yang penting. Perkembangan ilmu sosial pada tahun 1980-an, tingkat dukungan dan minat pemerintah terhadap ilmu sosial di Indonesia melebihi negara mana pun di Asia Tenggara. Hal 
ini adalah salah satu buah dari terkikisnya tradisi ilmu sosial kolonial alias indologie menjadi ilmu sosial developmentalis.

Daldjoeni (1985: 155) menjelaskan mengenai kemajuankemajuan di dalam perkembangan ilmu-ilmu social baik mengenai problematic, metodologi maupun pembentukan teorinya. Untuk menilai kemajuan dan kekurangan yang dialami oleh perkembangan tersebut, dapat dipakai titik tolak Mannheim yang mengatakan bahwa tata social akan mengalami keruntuhannya apabila kontrol rasional tak sejajar dengan perkembangan pengetahuan tentang masyarakat. Di samping itu terbukti pula bahwa rasionalitas dan kekuatan moril sebagai bekal pengendalian tak terbagi merata pada kelompokkelompok social yang ada. Dua macam hal diatas yang dapat mendatangkan keruntuhan.

Akibat saling ketergantungan antar gejala-gejala sosial meningkat, maka perilaku yang irasional semakin menimbulkan ekseseksesnya dalam masyarakat. Di samping itu demokratisasi yang mendasar di negeri-negeri Barat dapat berpengaruh pada kejadiankejadian sosial. Sebab itu masyarakat industri perlu ada pembaharuan pengenalan rasionalitas yang substantial untuk mengetahui tentang relasi anatar gejala social di dalam situasi tertentu. Perubahan sosial yang pesat sehingga membutuhkan tindakan-tindakan ilmu-ilmu alamiah (termasuk ilmu-ilmu teknik) dan ilmu-ilmu sosial. Di samping itu diperlukan kegiatan anekakesatuan social yang diperoleh dari faham-faham tertentu. Sehubungan dengan itu kini ilmu social di bagi atas bagian-bagian ayang bercorak menjelaskan obyeknya saja seperti ekonomi, sosiologi dan demografi. Masing-masing disiplin itu mengatur bagian informasi yang terbatas dari kehidupan social. Di samping itu ada ilmu-ilmu social penerapan seperti planologi (ilmu perencanaan kota) dan pedagogic social (ilmu pendidikan masyarakat).

Perkembangan ilmu-ilmu social kini memiliki dua arah. Pertama 
yang menuju kepada penelitian atas sistemnya. Kedua menuju kepada teori-teori penentuan. Ilmu social yang menjelaskan fungsinya disebut ilmu obyek, arena tugasnya menemukan pertalian yang ada didalam obyeknya ilmu-ilmu social yang baru dan ideal nantinya akan bersifat metodologis yang dapat diterapkan pada berbagai obyek studi yang berlainan. Nasiwan \& Wahyuni (2016: 11) persoalan perkembangan ilmu sosial di Indonesia dimulai dari ketidakmampuan dan ketidakpercayaan ilmuan, akademisi terhadap pemikiran orisinal yang bersumber dari masyarakat. Ketidakpercayaan ini menjadi penyakit bagi ilmuan, karena memaksa para peneliti untuk menggunakan dan menduplikasi teori-teori barat yang dianggap sebagai pusat ilmunya.

Beberapa masalah kemudian dimunculkan untuk melihat persoalan yang muncul dalam perkembangan ilmu sosial. Persoalan perkembangan ilmu sosial diadaptasi dari pemikiran Syed Farid Alatas (2003) yaitu: (1) ada pusat keberpihakan eurosentris sehingga ide, model, pilihan masalah, metodologi, teknik bahkan prioritas riset cenderung semata-mata berasal dari Amerika, Inggris, Perancis dan Jerman; (2) ada pengabaian umum terhadap tradisi filsafat dan sastra lokal; (3) kurangnya kreativitas atau ketidak-mampuan para ilmuan sosial untuk melahirkan teori dan metode yang orisinal; (4) peniruan dalam pengadopsian yang tidak kritis terhadap model ilmu sosial barat; (5) diskursus eropa terhadap masyarakat non barat cenderung mengarah pada kontruksi esensialis yang mengkonfirmasi bahwa non barat kebalikan dari eropa; (6) tidak adanya sudut pandang minoritas; (7) adanya dominasi intelektual negara dunia ketiga oleh kekuatan ilmu sosial eropa; (8) telaah ilmu sosial dunia ketiga dianggap tidak penting sebagian karena sifatnya yang polemis dan retorik dan konseptualisasi yang tidak memadai.

\section{Metode Penelitian}

Penelitian dilakukan dengan menggunakan metode kajian 
pustaka yaitu sebuah teknik mencari informasi melalui pustaka atau referensi yang ditulis oleh ilmuwan yang memiliki otoritas dalam bidang ilmu tertentu. Sumber data berasal dari berbagai buku dan referensi yang mempublikasikan gagasan Kuntowijoyo, Sartono Kartodirjo, Mubyarto, Zamroni, dan Purwo Santoso. Penelitian dilakukan dengan meneliti sumber-sumber pustaka yang mempunyai relevansi dengan pemikiran tokoh tersebut. Di samping perpustakaan, internet juga menyediakan informasi yang berkaitan dengan data-data yang dibutuhkan. Informasi dari internet seperti: jurnal online, kamus online, dan buku elektronik sangat membantu melengkapi sumber data peneliti sebagai bahan referensi untuk memahami, interpretasi, dan mempertajam analisis yang dilakukan.

Analisis data dilakukan dengan cara hermeneutik yaitu sebuah analisis yang menggunakan pemahaman (verstehen) dari tulisan atau pemikiran tokoh tertentu. Esensi dari kegiatan penelitian yang dilakukan adalah membaca referensi lain yang mendukung, baik secara simbolik maupun semantik. Membaca simbolik merupakan kegiatan membaca yang tidak menyeluruh, yaitu menangkap sinopsis dari bagian-bagian kecil buku. Tahap membaca simbolik penting artinya untuk menentukan peta penelitian serta mengembangkannya menjadi lebih luas. Sedangkan membaca semantik artinya: peneliti mengumpulkan data dengan membaca teks atau naskah secara lebih terinci, terurai dan berusaha untuk menangkap esensi dari data tersebut (Kaelan, 2005: 157). Sedangkan teknik pengumpulan data dilakukan dengan beberapa langkah yaitu: identifikasi, kodifikasi, klasifikasi, inter-pretasi, elaborasi, dan inferensi.

\section{Hasil Penelitian}

1. Pribumisasi Ilmu Sosial: Konteks Indonesia

Setiap ilmu pengetahuan pasti memiliki pikiran-pikiran dasar seperti asumsi dan prinsip yang digunakan untuk membentuk teori 
keilmuan. Jujun dalam (Santoso, 1986: 115-117) asumsi merupakan anggapan manusia terhadap realitas yang kebenarannya dapat diverifikasikan secara empiris, sehingga pada akhirnya menggunakan seperangkat prinsip yang berfungsi sebagai kriteria atau tolok ukur dalam analisisnya. Faktor ilmu pengetahuan tersebut sangat penting bagi perkembangan ilmu-ilmu social, sehingga proses pribumisasi melalui identifikasi asumsi dasar dalam ilmu- ilmu sosial sangat perlu agar diperoleh suatu konsepsi ilmiah yang relevan dengan kondisi yang diamati.

Pribumisasi atau indigeneus merupakan istilah yang berasal dari bahasa latin yaitu asli, pribumi. Ignas Kladen (1997: 30) menyatakan bahwa pribumisasi sebagai gerakan partikularisme, artinya kencenderungan untuk mengecualikan ilmu sosial Indonesia dari komunitas ilmu sosial internasional. Permasalahan sosial yang ada tidak dapat di selesaikan dengan komunitas akademis internasional melainkan diselesaikan dengan historis kultur yang dimiliki oleh suatu negara. Istilah pribumisasi dapat dimaknai sebagai berikut pertama, pribumisasi diartikan sebagai domestikasi, islamisasi, partikularisasi. Kedua, pribumisasi dimaknai sebagai upaya membangun teori khas yang digali dari unsur etnik, budaya, atau agama yang sesuai dengan komunitas pendukungnya. Ketiga, pribumisasi bermakna penyelesaian teori yang sesuai dengan keadaan Indonesia.

Pribumisasi tidak hanya terbatas dalam sebuah makna saja akan tetapi mempunyai ruang gerak dalam mengaktualisasi ilmuilmu sosial dalam realitas (Nasiwan, 2013:116). Pada saat ini menjadi isu yang serius terhadap keberadaan ilmu-ilmu sosial yang mengalami kemandegan dan minimnya kontribusi ilmuan sosial baik dalam tataran teoritik maupun metodologi. Ilmuan ilmu-ilmu sosial sekarang mengalami kesulitan dalam mengidentifi-kasikan pikiranpikiran dasar yang cocok terhadap situasi konteks-tual, yang 
kemudian mengalami kegagalan dalam memilih konsep ilmiah yang sesuai. Isu pribumisasi lahir sebagai jawaban atas kritik yang dilontarkan pada ilmu-ilmu sosial di Indonesia karena ilmu-ilmu sosial di Indonesia masih didominasi oleh ilmu-ilmu yang dari Barat. Masalah yang fatal ketika ilmuan yang mendapatkan pendidikan di Barat dan setelah lulus tidak dapat menerapkan ilmu-ilmu tersebut berdasarkan keadaan dan kondisi di Indonesia. Pada saat ini ilmuilmu sosial di negara berkembang khususnya Indonesia masih berkiblat terhadap ilmu Barat. Sehingga pada konteks isinya belum ada yang didasarkan pada histori bangsa sendiri (Santosa, 1997: 188).

Cendekiawan Muslim Indonesia yang memberikan kritikan tajam tentang perkembangan ilmu sosial di Indonesia yang mengalami kemandekan bahkan kehilangan kerangka nilai yang mampu mengarahkan kemana transformasi masyarakat Indonesia digerakkan. Dalam kaitan ini untuk memperbaiki kondisi ilmu-ilmu sosial di Indonesia Kuntowijoyo mengusulkan perlu memberikan ruang untuk hadirnya apa yang disebut Ilmu Sosial Profetik (Nasiwan \& Hendrastomo, 2012: 198). Sedangkan Djalong (2006: 2) menekankan bahwa ilmu-ilmu sosial modern tidak seluruhnya ditolak, melainkan dicoba didapatkan relevansinya dengan kondisi dan kebutuhan masyarakat lokal. Dari pengertian bisa ditangkap suatu penalaran sederhana bahwa persoalan yang melekat pada rezim ilmu-ilmu sosial bukanlah bersifat epistemologis tentang bagaimana suatu pengetahuan terbentuk dan beroperasi sebagai sebuah cara berpikir kolektif. Kontekstualisasi ilmusemata-mata menyiratkan persoalan ilmiah yang metodologis sifatnya. Barangkali juga karena yang umum berlaku adalah penalaran semacam ini maka dalam beberapa tahun terakhir komunitas ilmu sosial di Indonesia amatlah antusias menyambut dan kemudian menereapkan model apropriasi fakta yang dikembangkan ilmuwan sosial seperti Jurgen Habermas 
dengan pendekatan partisipatorisnya. Tugas ilmu sosial kemudian disederhanakan sebagai misi pencerahan dan emansipasi manusia dari kungkungan ketidaksadaran sistematis dalam mana ilmuwan sosial dituntut lebih dekat dengan subyek atau obyek penelitiannya.

Menurut Jurdi (2017: 43) kemandekan ilmu sosial di Indonesia dipengaruhi oleh faktor yang saling mempengaruhi yakni; pertama, proses transformasi sosial dan dinamika kekuasaan telah membentuk orientasi tersendiri bagi ilmu-ilmu sosial tidak hanya berkaitan dengan pentingnya pusat kekuasaan memahami persoalan empirik yang dihadapi oleh masyarakat yang dipimpinnya, tetapi juga untuk merekontruksi tata kehidupan sosial yang mencerminkan realitasyang hidup dalam masyarakat. Kedua, rendahnya sikap asketisme ilmuwan sosial Indonesia untuk mengembangkan ilmu yang bersesuaian dengan karakter dasar masyarakat. Antara kuatnya kepentingan otoritas politik dengan rendahnya semangat ilmuwan sosial, akan mengikis bahkan menumpulkan optimisme membangun tradisi ilmu sosial sendiri.

Pribumisasi merupakan sikap ketidakpuasan terhadap ilmu sosial Barat yang dikembangkan disuatu kawasan, karena dianggap tidak mampu menjelaskan dan memecahkan problem masyarakat yang timbul. Pribumisasi merupakan metode alternatif terhadap ketidakpuasan ilmuan atas dominasi ilmu sosial barat pada ilmu sosial pribumi. Pribumisasi (indegenousasi) ilmu-ilmu sosial saat ini sangat penting dilakukan untuk menumbuhkan pemikiran-pemikiran baru dalam mengembangkan ilmu-ilmu sosial di Indonesia. Kondisi pada saat ini sangat memerlukan ilmuan ilmu sosial yang dapat mengembangkan ilmunya berasal dari histori atau sejarah bangsa Indonesia. Histori atau sejarah dapat menjadi penghubung masa kini dan masa lalu untuk gambaran dimasa yang akan datang. permasalahan sosial suatu negeri tidak dapat diselesaikan dengan cara internasional melainkan dengan cara lokal yaitu dengan kultur 
historis yang dimiliki suatu bangsa. Masalah-masalah sosial yang ada dapat diseslesaikan dengan menagacu pada perkembangan zaman yang terjadi.

Setidaknya ada 3 alasan pentingnya melakukan pribumisasi Ilmu Sosial di Indonesia yaitu; pertama, ilmu-ilmu sosial di negara berkembang berawal dari Barat sehingga di kerangka teoritis, prinsip metodologi, pengetahuan atas pengetahuan yang dibentuk disana belum tentu sejalan dengan di Indonesia. Kedua, ilmu pengetahuan selalu mencari bentuk praksisnya, yang tidak berbicara tentang pentingnya konteks tetapi juga tidak lepas dengan pengaruh ideologi. Ketiga, teori-teori yang lahir dalam konteks masyarakat Barat memiliki keterbatasan daya-penjelas dalam konteks masyarakat Indonesia. Selama teori dibangun dari masyarakat maka teori yang ada akan memuat kekosongan jika digunakan pada konteks yang berbeda (Martanto, 2012: 11-16).

Santoso (2003: 63) para penganjur pribumisasi mempunyai tiga alasan utama pentingnya melakukan pribumisasi. Pertama, alasan akademis artinya ilmu sosial di Dunia Ketiga, berawal, berpreferensi, dan dikembangkan atas dasar filsafat dan kepercayaan Barat. Negara Dunia Ketiga sebenarnya akan lebih efektif jika membentuk ilmu sosial sendiri berdasarkan temuan lokal dan diorganisasikan berdasarkan penjelasan setempat. Kedua, alasan ideo-logis yaitu sebagai reaksi atas ideologi kolonial. Ketiga, alasan teoritis, artinya teori sosial tidak semata-mata memiliki daya penjelas, untuk menambah kepercayaan diri dan menghindari manipulasi dari suatu teori. Berdasarkan alasan tersebut Pribumisasi diperlukan untuk membentuk ilmu sosial yang khas, yang berwajah sesuai dengan wajah Indonesia yang diambil dan dibangun berdasarkan preferensi lokal yang juga dijelaskan dalam konteks lokal.

Mempelajari ilmu sosial akan menjadi berkembang ketika tidak ada patokan yang membatasi dalam suatu materi. Ilmu sosial sangat 
terpadu sekali isinya sehingga dalam mata pelajaran akan lebih sesuai jika memegang konsep keterpaduan pada pembelajaran. Saat ini ilmuan seperti guru dan dosen hanya sebagai alat penyalur materi yang telah disiapkan untuk peserta didik. Ilmuan tidak dapat keluar dari patokan keilmuan barat yang sudah disediakan.

Somantri (2005: 169) menekankan untuk meminimalisir ilmu sosial mengalami penurunan pada perkembangan yaitu dengan upaya penciptaan ilmu sosial pada format yang lebih otonom. Diperlukan posisi ilmu sosial di Indonesia pada fondasi yang lebih kontekstual dan historis. Artinya menyepadankan aspek meteodologis serta posisi premis teoritis pada konteks di Indonesia itu sendiri. Ilmuwan sosial sekarang belum mampu menjelaskan dari permasalahan tersebut. Sehingga terdapat berbagai penawaran yang diberikan dari para tokoh untuk menemukan teori sosial alternatif yang mengarah pada pribumisasi. Ilmuwan sosial Indonesia yang menjadi pioneer pribumisasi dapat dijelaskan sebagai berikut.

a) Kuntowijoyo dengan gagasan tentang ilmu sosial protefik (ISP) sebagai suatu ilmu sosial yang tidak hanya menjelaskan dan mengubah fenomena sosial tetapi juga memberi petunjuk ke arah mana transformasi dilakukan, untuk apa, dan oleh siapa. ISP tidak mengubah berdasarkan perubahan namun berdasarkan cita-cita etik dan profetik. Perubahan yang diinginkan oleh Kuntowijoyo adalah perubahan pada cita-cita humanisasi/emansipasi, liberasi, transdensi yang terkandung dalam misi Islam. Orientasi ISP terhadap Epistemologi yaitu bahwa sumber ilmu pengetahuan itu tidak hanya dari rasio dan empiris namun dapat berasal dari wahyu.

b) Sartono Kartodirjo seorang sejarawan yang mengembangkan ilmu sejarah multidimensi yang lebih mengarah pada historiografi dari Eropa-sentris menjadi Indonesia-sentris. Mengandung maksud bahwa ilmu sejarah yang semula berorientasi pada kebudayaan 
Barat dirubah menjadi sejarah kebudayaan Indonesia. Dengan pendekatan barunya dalam metode sejarah Sartono Kartodirdjo bukan hanya menawarkan pribumisasi ilmu sejarah, namun juga pendekatan yang lebih komprehensif dengan menggunakan ilmu sosial lainnya sebagai alat analisis.

c) Mubyarto merupakan tokoh perintis pribumisasi ilmu ekonomi yang menawarkan konsep ekonomi Pancasila. Gagasan utama yang ditawarkan oleh Mubyanto diantaranya sebagai berikut: roda perekonomian digerakan oleh rangsangan ekonomi, sosial, dan moral; kehendak kuat dari seluruh masyarakat ke arah keadaan kemerataan sosial (egaliterianisme) sesuai dengan asas kemanusiaan; prioritas kebijakan ekonomi adalah penciptaan perekonomian nasional yang tangguh yang berarti nasionalisme menjiwai setiap kebijakan ekonomi; koperasi merupakan soko guru perekonomian dan merupakan bentuk paling konkret dari usaha bersama.

d) Purwa Santoso yang menawarkan Ilmu sosial transformatif yang dimaksud ialah mencakup berbagai disiplin ilmu sosial, diantaranya sosiologi, ilmu politik, ilmu ekonomi, antropologi, sejarah, ilmu hukum dan lainnya. Dasar dalam tranformatif disini ialah kejelasan dalam epistemologisnya. Sehingga dalam mengembangkan ilmu sosial metodologi yang digunakan mengedepankan objektivitas tidak harus ditolak namun diberi kenaifan. Kemudian diberikan cara untuk mengkompensasi keperluan untuk transformatif. Nasiwan (2013 :118) menjelaskan cara-cara pribumisasi yang diusulkan oleh Purwa Santoso sebagai berikut: ada kebijakan politik keilmuan yang dirumuskan oleh pemerintah; metodologi diajarkan sebagai suatu keterampilan; menjembatani praktek berbasis kearifan lokal dengan kegiatan di kampus; adanya imbangan yang jelas dan tegas antara perencanaan di tingkat nasional dengan desentralisasi dalam 
pelaksanaan kegiatan ekonomi untuk menjamin keadilan ekonomi dan sosial.

e) Zamroni menawarkan pribumisasi ilmu sosial dalam pendidikan yang menginisiasi beberapa hal yaitu: orientasi good citizenship dengan menitikberatkan pada pengembangan nilai-nilai luhur tradisi bangsa melalui nasionalisme, toleransi, cinta tanah air, bekerja keras dan jujur; mengembangkan keterampilan pada diri siswa untuk melakukan pengamatan, pengumpulan data dan penguasaan teori; mengembangkan kemampuan berfikir reflektif dengan penekanan pada analisis kritis, analisis nilai dan berfikir nasional; melakukan inovasi sosial dengan mengkaji, mengkritik, dan merevisi praktik-praktik sosial dan cara pemecahan masalah yang ada selama ini; dan terakhir menanamkan jatidiri dan sifat positif.

Dalam pandangan Cholisin (2012) universitas sesuai dengan karakteristiknya harus mampu memproduksi ilmu pengetahuan melalui penelitian yang dilakukan. Ilmu pengetahuan yang dihasilkan tentunya harus disesuaikan dengan nilai dan kepentingan masyarakat Indonesia. Nilai dan kepentingan masyarakat Indonesia yaitu Pancasila dan tujuan negara seharusnya menjadi acuan dalam melahirkan ilmu-ilmusosial di Indonesia. Diperlukan upaya untuk melakukan revolusi ilmu sosial berupa pribumisasi ilmu sosial di Indonesia dengan menggali budaya lokal serta bersifat historis atau tidak meninggalkan sejarah yang dimiliki oleh Indonesia.

2. Pribumisasi IPS Terpadu: Konteks Pembelajaran di Sekolah

Memasuki abad XXI bangsa Indonesia menghadapi permasalahan yang amat krusial dalam kehidupan berbangsa dan bernegara. Seiring dengan berkembangnya globalisasi, bangsa Indonesia mema-suki sebuah zaman dimana keterbukaan, liberalisasi, dan komer-sialisasi menjadi arus utama yang harus diikuti untuk dapat eksis dalam percaturan kehidupan global. Era 
globalisasi yang sedang berjalan dan bergulir di dalam kehidupan, mengingatkan kita pada Alvin Toffler (1997) yang menyatakan bahwa dunia sedang memasuki peradapan "gelombang ke tiga" yaitu peradapan pasca industri yang ditandai dengan kemajuan yang sangat pesat dalam teknologi informasi, yang sudah menjadi salah satu ciri utama arus globalisasi.

Dampaknya adalah teralienasinya budaya kerjasama atau gotong royong (cooperative), hilangnya kepercayaan (distrust), dan makin menguatnya gaya hidup konsumeris-hedonistis. Irwan Abdullah (2019: 7) menyebutkan problem kepedulian sosial yang semakin rendah di masyarakat yang ditunjukkan dengan tiga bentuk yaitu: selfisme (mendewakan diri sendiri), keserakahan eksklusif (berpuas diri menikmati kejayaan yang tidak mau diusik), apatisme terhadap kehidupan yang lebih baik. Sementara itu melunturnya semangat kerja dan semangat belajar di kalangan siswa karena lebih memilih untuk bermain game, play station, atau aktivitas lain yang tidak produktif juma menjadi keprihatinan kita bersama.

IPS sebagai mata pelajaran yang memiliki kaitan erat dengan disiplin ilmu sosial dan humaniora bertujuan untuk mempersiapkan peserta didik sebagai warga negara yang memiliki pengetahuan (knowledge), sikap (attitudes), dan ketrampilan (skills). Oleh karenanya IPS merupakan suatu kajian dengan identitas eklektik sebagai synthetic discipline, multidimensional yang berbeda dengan ilmu sosial tradisional yang sifatnya monodisiplin (Sapriya, 2017: 13). Dalam konteks tersebut maka IPS perlu juga melakukan pribumisasi dalam bidang pengajaran dengan menggunakan berbagai alternatif. Hal tersebut ditujukan untuk memberikan landasan yang kokoh kepada peserta didik agar dapat berkembang menjadi warga negara demokratis, kritis, dan trampil secara sosial.

Dalam konteks tersebut, Sapriya (2017) meminta agar pembelajaran IPS di sekolah dasar dan menengah berorientasi pada 
peningkatan kemampuan berfikir kritis melalui berbagai pendekatan seperti inkuiri, menekankan pada introduksi ilmu, teknologi, dan masyarakat global serta mengembangkan partisipasi dan kepekaan sosial. Beberapa penelitian yang telah dilakukan oleh para ilmuwan maupun praktisi merupakan harapan baru untuk melakukan pembaruan pembelajaran IPS di sekolah.

Sudrajat (2014: 1-19) mencoba menawarkan konsep pengajaran IPS di sekolah dasar dengan format pendidikan multikultur. Penerapan pembe-lajaran IPS dengan format pendidikan multikultur untuk meningkatkan kerjasama dan penghormatan pada individu di SD Negeri 2 Kadipiro memberikan suatu perspektif bahwa pendidikan IPS perlu melakukan pembaruan metode dengan mengintroduksi metode pengajaran yang baru kepada guru agar kualitas pembelajaran IPS di sekolah dasar menjadi lebih baik.

Mengintegrasikan karakter dalam pembelajaran IPS juga merupakan aspek yang penting disebabkan oleh semakin kuatnya degradasi moral di dalam masyarakat Indonesia. Kajian seperti yang telah dilakukan oleh Wijayanti (2019: 70-86) tentang integrasi nilai kearifan lokal di sekolah menengan perlu terus dilakukan agar upaya inovatif yang dilakukan dunia pendidikan dapat teridentifikasi dan diduplikasi oleh satuan pendidikan lainnya. Upaya memperbarui, inovasi, kreasi perlu mendapat perhatian dari segenap pemangku kepentingan agar pribumisasi ilmu sosial melalui pembelajaran dapat berjalan secara evolusioner. Yang tidak kalah pentingnya adalah bagaimana mendesain pembelajaran IPS agar lebih menarik dan kontekstual. Supardi, Widiastuti \& Saliman (2015: 1-21) yang melakukan penelitian pengembangan media pembelajaran IPS berbasis audiovisual juga perlu terus digalakkan. Media pembelajaran dengan tema "antara Borobudur dan Prambanan" teruji secara empirik dapat meningkatkan antusiasme peserta didik untuk memahami dan menganalisis peninggalan sejarah Indonesia serta 
karakteristik masyarakatnya pada masa tersebut.

\section{Simpulan}

Ilmu sosial merupakan ilmu yang mempelajari perilaku dan aktivitas manusia dalam kehidupan bersama dan memiliki beberapa ruang lingkup yaitu sosiologi, ekonomi, sejarah, geografi, psikologi, politik, linguistik, antropologi dan pendidikan. Perkembangan ilmu sosial di Indonesia melalui tiga fase, yaitu ilmu sosial kolonial (indologi); ilmu sosial develomentalis; dan ilmu sosial kontemporer. Masing-masing fase memiliki karakteristik yang berbeda-beda. Namun perkembangan ilmu sosial di Indonesia mengalami ketidakmampuan dan ketidakpercayaan ilmuan, akademisi terhadap pemikiran orisinal yang bersumber dari masyarakat. Ketidakpercayaan ini menjadi penyakit bagi ilmuan, karena memaksa para peneliti untuk menggunakan dan menduplikasi teori-teori Barat.

Pribumisasi ilmu sosial di Indonesia dapat dilakukan menggali budaya lokal, melakukan pembaruan dalam pembelajaran baik esensi, metode, media, maupun desain pembelajarannya agar lebih kontekstual. Berbagai hasil penelitian terutama penelitian pengembangan menjadi kunci penting untuk membuka jalan menuju IPS Terpadu yang kontekstual dan menjadi jembatan bagi diseminasi kajian sosial yang dilakukan oleh ilmuwan sosial. Peran guru dan praktisi dengan demikian menjadi penting sebagai salah satu mata rantai pribumisasi ilmu sosial Indonesia.

\section{Reference}

Alatas, S. F. (2003). Pangkajian Ilmu-Ilmu Sosial: Menuju ke Pembentukan Konsep Tepat. Jurnal Antropologi Indonesia (72).

Cholisin. (2012). Peran Universitas dalam Mengatasi Problematika Pengembangan Ilmu Sosial. Prosiding Diskusi Perkembangan dan Problematika Pengembangan Ilmu Sosial di Indonesia Kontemporer. Universitas Negeri Yogyakarta: Fakultas Ilmu Sosial. 
Daldjoni. (1985). Dasar-dasar Ilmu Pengetahuan Sosial. Bandung: Alumni

Djalong, F. (2006). Indegenisasi Ilmu-Ilmu Sosial: Sebuah Persoalan. Jurnal Sintesa, 7, (2). 45-67.

Ijtimayati. (2018). Hubungan Antara Ilmu-Ilmu Sosial dan IPS (Sumber \& Materi IPS). Jurnal Ilmu Sosial, 2, (1). 9-20.

Kleden, I. (1988) Sikap ilmiah dan kritik kebudayaan. Jakarta: LP3ES.

Jurdi, S. (2017). Ilmu Sosial, Budaya Intelektual \& Semangat Kenabian: Telaah Pengembangan Ilmu Sosial Nusantara. The Journal of Society \& Media. 1, (2). 67-80.

Martanto, U. (2012). Matinya Ilmu Sosial di Indonesia: Indigenisasi Reflektif Emansipatif. Jurnal Politik Indonesia, 1, (1). 11-16.

Nasiwan \& Hendrastomo, G. (2012). Dari Diskursus Alternatif Menuju Indigeneousasi Ilmu Sosial Indonesia: Teoritisasi "Prophetic Political Education". SOCIA , 11, (2).

Nasiwan \& Wahyuni, Y, S. (2016). Teori-teori Sosial Indonesia. Yogyakarta: UNY Press.

Nasiwan. (2014). Menuju ilmu sosial profetik. Yogyakarta: Prima Print.

Santoso, Heri. (2003). Filsafat Ilmu Sosial: Ikhtiar Awal Pjurribumisasi Ilmu-Ilmu Sosial. Yogyakarta: Bama Media.

Sapriya, (2017). Pendidikan IPS: konsep dan pembelajaran. Bandung: Rosdakarya.

Somantri, G. R. (2005). Membebaskan Ilmu Sosial dari Keterperangkapan Ganda, Jurnal Ilmu Sosial dan Ilmu Politik, 9, (2), 159-178

Sudrajat, (2014). Pendidikan multikultural untuk meningkatkan kualitas pembelajaran IPS di sekolah dasar, JIPSINDO, 1, (1), 119.

Supardan, D. (2011). Pengantar Ilmu Sosial: Sebuah Kajian Pendekatan Struktural. Jakarta: PT Bumi Aksara

Supardi. (2011). Dasar-Dasar Ilmu Sosial. Yogyakarta: Ombak.

Supardi, Widiastuti, A., \& Saliman (2015). Pengembangan media pembe-lajaran IPS Terpadu berbasis audiovisual, JIPSINDO, 2, (1), 1-21.

Wijayanti, A., T. (2019). Penguatan nilai kearifan lokal melalui penerapan petruk, JIPSINDO, 6, (1), 70-86. 